\title{
Examining Linkage Audit Quality Factors Intervening by Time Budget Pressure
}

\author{
Mohammad Aldrin Akbar ${ }^{1 *}$, Najarudin Toatubun ${ }^{2}$, Abdul Haris Mzen ${ }^{3}$, Imran Syafei \\ Muhammad Nur ${ }^{4}$, Septyana Prasetianingrum ${ }^{5}$ \\ 1,2,3,4,5 Department of Accounting, Faculty of Economic and Business, University Yapis Papua, \\ Papua, Indonesia \\ Email address: \\ aldrinakbar160@gmail.com ${ }^{1}$,najartoat@gmail.com², harismzen@gmail.com², \\ imransyafei27@gmail.com ${ }^{4}$,prasetyaningrumseptyana@gmail.com ${ }^{5}$ \\ ${ }^{*}$ Corresponding author \\ aldrinakbar160@gmail.com ${ }^{1}$
}

\begin{abstract}
Public accountants are independent auditors who provide services to the general public, especially in auditing financial statements made by their clients. The task of a public accountant is to examine and give an opinion on the fairness of the financial statements of a business entity based on predetermined standards. The public accounting profession is responsible for increasing the reliability of the company's financial statements. The public can obtain reliable financial statement information as a basis for decision-making. The research objective is to answer the phenomenon of the variable, namely the Effect of Auditor Competence, Audit Complexity, Auditor Independence on Audit Quality. The research method uses Multiple Regression Analysis. From the research results obtained the following results Auditor Independence has the most dominant effect on Audit Quality, Audit Complexity also has a significant but negative impact on Audit Quality. Meanwhile, Auditor Competence also significantly impacts Audit Quality.
\end{abstract}

Keywords: Competence, Independence, Risk Based Audit, Quality Audit.

\begin{abstract}
Abstrak: Akuntan publik adalah auditor independen yang memberikan jasa kepada masyarakat umum, khususnya dalam mengaudit laporan keuangan yang dibuat oleh kliennya. Tugas akuntan publik adalah memeriksa dan memberikan pendapat atas kewajaran laporan keuangan suatu badan usaha berdasarkan standar yang telah ditetapkan. Profesi akuntan publik bertanggung jawab untuk meningkatkan keandalan laporan keuangan perusahaan. Publik dapat memperoleh informasi laporan keuangan yang andal sebagai dasar pengambilan keputusan. Tujuan penelitian untuk menjawab fenomena variabel yaitu Pengaruh Kompetensi Auditor, Kompleksitas Audit, Independensi Auditor terhadap Kualitas Audit. Metode penelitian menggunakan Analisis Regresi Berganda. Dari hasil penelitian diperoleh hasil sebagai berikut Independensi Auditor berpengaruh paling dominan terhadap Kualitas Audit, Kompleksitas Audit juga berpengaruh signifikan namun negatif terhadap Kualitas Audit. Sementara itu, Kompetensi Auditor juga berpengaruh signifikan terhadap Kualitas Audit.
\end{abstract}

Kata Kunci: Kompetensi, Independensi, Audit Berbasis Risiko, Kualitas Audit. 


\section{INTRODUCTION}

The public accounting profession is a profession of public trust. From the public accounting profession, the public expects a free and impartial assessment of the information presented by company management in the financial statements (Durocher and Fortin, 2021). The public accounting profession is responsible for increasing the level of reliability of the company's financial statements so that the public can obtain reliable financial statement information as a basis for decision-making. To support his professionalism as a public accountant, the auditor must be guided by the audit standards set by the Indonesian Institute of Accountants (IAI), namely general standards, fieldwork standards, and reporting standards. The available standard reflects the personal qualities that an auditor must possess, which requires the auditor to have sufficient technical expertise and training in carrying out audit procedures.

Meanwhile, fieldwork standards and reporting standards regulate the auditor's data collection. Other activities carried out during the audit required the auditor to prepare a report on the financial statements. However, in addition to auditing standards, public accountants must also comply with the professional code of ethics that regulates the behavior of public accountants in carrying out their professional practices, both with fellow members and with the general public. This code of ethics handles professional responsibilities, professional competence and prudence, confidentiality, professional behavior, and technical standards for an auditor in carrying out his profession.

Public accountants or independent auditors in their duties to audit client companies have a strategic position as a third party in the client company environment, namely when public accountants carry out the duties and responsibilities of management (agents) to audit the companies' financial statements manage. In this case, the administration wants its performance to always look good in the eyes of external parties, especially the owner (principal). However, on the other hand, the owner (principal) wants the auditor to honestly report the situation in the company that has been financed. From the description above, it can be seen that there is a different interest between management and users of financial statements. The great trust of users of audited financial statements and other services provided by public accountants ultimately requires public accountants to pay attention to the quality of the audits they produce. The questions from the public about the quality of audits made by public accountants are getting bigger after many scandals involving public accountants both abroad and domestically. The domestic scandal can be seen from the action taken by the Honorary Council of the Indonesian Institute of Accountants (IAI) against 10 Public Accounting Firms. They were indicated to have committed severe violations when auditing the liquidated banks in 1998. In the context of the financial scandal above, it raises the question of whether these engineering tricks could be detected by the public accountant who audited the financial statements or had been detected. Still, the auditors participated in securing the criminal practice. Of course, if what happens is that the auditor is unable to see financial statement engineering tricks, then the core of the problem is the competence or expertise of the auditor. However, if what happens is that public accountants participate in securing the engineering practice, as was also revealed in the scandals that occurred Enron, Andersen, Xerox, WorldCom, Tyco, Global Crossing, Adelphia, and Walt Disney (Li, 2010), then the core problem is independence. The auditors. Related to this context, the question arises whether the current level of competence and independence of auditors is and 
whether the competence and independence of auditors affect the quality of audits produced by public accountants.

\section{THEORITICAL REVIEW}

This audit quality is essential because reliable financial reports will be produced as a basis for decision-making with high audit quality. In addition, there are concerns that financial scandals will spread, which could erode public confidence in audited financial reports and the public accounting profession. De Angelo (Agyei-Mensah, 2019) defines audit quality as the probability (joint probability) that an auditor will find and report violations in his client's accounting system. The likelihood that the auditor will discover misstatements depends on the quality of the auditor's understanding of competence. In contrast, the act of reporting misstatements relies on the independence of the auditor. Meanwhile, the AAA Financial Accounting Committee (2000) in (Cipriani, 2010) states that "audit quality is determined by two things, namely competence and independence." Both of these things directly affect the quality of the audit. In this regard, (Agusti and Pertiwi, 2013) define a competent person as a person who does work efficiently, quickly, intuitively, and very rarely or never makes mistakes. In line with Trotter's opinion, (Sofyan et al., 2015); (Samagaio and Felício, 2022) defines competence as having extensive procedural knowledge and skills demonstrated in audit experience. Meanwhile, (Athavale et al., 2022) said that auditors need auditing knowledge (general and specific), knowledge of auditing and accounting fields, and an understanding of the client's industry to perform auditing tasks.

In carrying out the audit, the auditor must act as an expert in accounting and auditing. Achievement of expertise begins with formal education, followed by experience and practice in auditing (Schmidthuber et al., 2020). In addition, auditors must undergo sufficient technical training, covering both technical and general education aspects.

Research conducted by (Moroney and Trotman, 2016); (Natsir et al., 2021) found that experienced auditors better understand financial statements. They are also better able to provide reasonable explanations for errors in financial statements and classify errors based on audit objectives and the structure of the underlying accounting system. Then (Carrera and Van Der Kolk, 2021) succeeded in showing that the more experienced the auditors are, the more sensitive they are to misstatements of financial statements, and the more they understand things related to the errors they find.

From (Dewayanto, 2011) research in 2014 found that audit complexity has a negative effect on audit quality, this negative result. To improve the auditor's ability to understand and master information systems, an auditor should attend training, seminars, and audit training related to auditing. That information system. This increased understanding will help reduce the complexity of audit assignments and help the auditor produce quality reports. Research from Totok Dewayanto uses the audit complexity variable as the dependent variable, accompanied by the experience variable, time budget pressure, and understanding of information systems as the independent variables. The difference in further research from Totok Dewanto's research is adding the auditor independence variable as the independent variable. This is deemed necessary because independence is felt to be required to examine whether it affects the quality of the audit or vise versa. Another thing added in this study is the dimension of knowledge and experience, which is an indicator of the competence 
variable as an independent variable which is following its responsibility to increase the level of reliability of a company's financial statements; public accountants not only need to have competence or expertise but also must be independent in auditing. Without independence, the auditor means nothing. The public does not believe in the auditors' audited results, so the people will not ask for auditing services. Or in other words, the existence of auditors is determined by their independence, and this refers to the results of research from (Usmany, 2021). Research on audit quality is essential for KAP and auditors to find out the factors that affect audit quality and can further improve the quality of the audit they produce. For users of audit services, this research is essential to assess the extent to which public accountants can be consistent in maintaining the quality of the audit services they provide.

Competence of auditors are auditors who, with sufficient and explicit knowledge and experience, can conduct audits objectively, carefully, and thoroughly. Audit quality is all about possibilities (probability). While carrying out their duties, the auditor can find violations in the client's accounting system and report them in the audited financial statements. The auditor is guided by auditing standards and the relevant public accountant code of ethics. Therefore, it can be understood that an auditor who has adequate knowledge and experience will better understand and know various problems in greater depth, and it is easier to follow increasingly complex developments in his client's audit environment. So, it can be concluded that the higher the auditor's competence, the higher the quality of the audit it produces. Research results (Liahmad et al., 2020) says that audit quality is determined by two things, namely competence (expertise) and independence. These two things directly affect the quality and potentially influence each other. Research conducted by (Endri, 2020); (Imen and Anis, 2020); (Ab Wahid and Grigg, 2020); (Trotman and Trotman, 2010) overall argues that competence has a significant effect on audit quality. It is emphasized again from research by (Alzeban, 2019), which states that experience may be necessary for complex decisions but not routine and structured decisions. The effect of experience will be significant as the tasks performed are increasingly demanding.

(Aida, 2021) found an inverse relationship between task complexity and audit quality at a certain level. The higher the complexity of the task, the lower the audit quality will be and vise versa. In their research, (Jaya and Irene, 2016) also found that audit complexity that arises due to the higher variability and ambiguity of auditing tasks indicates the cause of the decline in audit quality. In such situations, auditors tend to behave dysfunctionally and prioritize the interests of clients rather than the objectivity of the audit results. However, (Aida, 2021) finds different effects, namely that task complexity does not affect the judgment made by the auditor in determining his audit opinion. These studies indicate that task complexity is not consistent as a factor affecting audit quality. Therefore, further research is necessary to decide on task complexity in audit quality. Competence is associated with audit quality. Studies conducted by (Zahmatkesh and Rezazadeh, 2017) show that competence significantly affects audit quality. This is contrary to the research undertaken by (Furiady and Kurnia, 2015), which shows the low level of significance of the competency variable, thus proving that competence does not affect audit quality. Independence is the attitude expected of a public accountant who does not have a personal interest in carrying out his duties, contrary to the principles of integrity and objectivity. Therefore, it is quite reasonable that an independent attitude from the auditor is needed to produce a quality audit. Because the auditor loses independence, the audit report delivered does reflect the existing reality, so it cannot be used as a basis for decision-making. This is following the following 
searches by (Kertarajasa et al., 2019), which in their research results explain that independence has a significant effect on audit quality. Next, the research results from (Putri et al., 2021) measure independence using four factors: client relationships, pressure from clients, reviews from auditors, non-auditors, and they also argue that the four factors summarized in the independence variable also significantly affect audit quality.

While (Daniels and Booker, 2011) research state that independence significantly impacts audit quality. Furthermore, on other variables such as work experience, which is associated with audit quality, a previous study conducted by (Rajgopal et al., 2021) showed that work experience had a positive and significant effect both partially and simultaneously, while research conducted by (Liu and Xu, 2021), shows that audit experience does not have a considerable impact on the quality of audit results. In carrying out the audit process, auditors need good knowledge and experience. With these two things, the auditor can better understand their clients' financial condition and financial statements. Then, with an attitude of independence, the auditor can report in the audit report if there is a violation in the client's financial statements. So, based on the logic above, competence and independence influence the production of a good audit. According to (Broberg et al., 2017) research, the results show that time budget pressure has a negative effect on audit quality. Likewise, in (Svanberg and Öhman 2013) study, the results showed that time budget pressure makes auditors tend to take actions that cause a decrease in audit quality. (Ahmad and Taylor, 2009) state that complexity arises from ambiguity and weak structure, both in the main tasks and other tasks. In ambiguous and unstructured studies, alternatives cannot be identified, data cannot be obtained, and there is unpredictable output. (Aziz et al., 2021) put forward the same argument that the complexity of the task in auditing is influenced by several factors, namely: the amount of information that is irrelevant in the sense that the data is inconsistent with the events to be predicted. There is high ambiguity, namely the variety of outcomes (results). In their research, (Setyowati et al., 2021) also state a significant influence between audit complexity and audit quality. Based on the existing background, the formulation of the problem in this study is do the audit's competence, independence, and complexity affect the audit's quality?

\section{METHODS}

This study combines various models of the relationship between variables (e.g., direct effect, indirect effect, and Intervening effect). To simplify the reader's understanding of the topic and theme of this study, we illustrate a series of research in the form of a conceptual framework, as shown in Figure 1. In this illustration, we arrange direct, intervening, and indirect relationships, then be demonstrated using the application. SmartPLS 3.0 follows the description of the hypothesis that has been described previously. This study involved 35 auditors from BPKP Jayapura. 


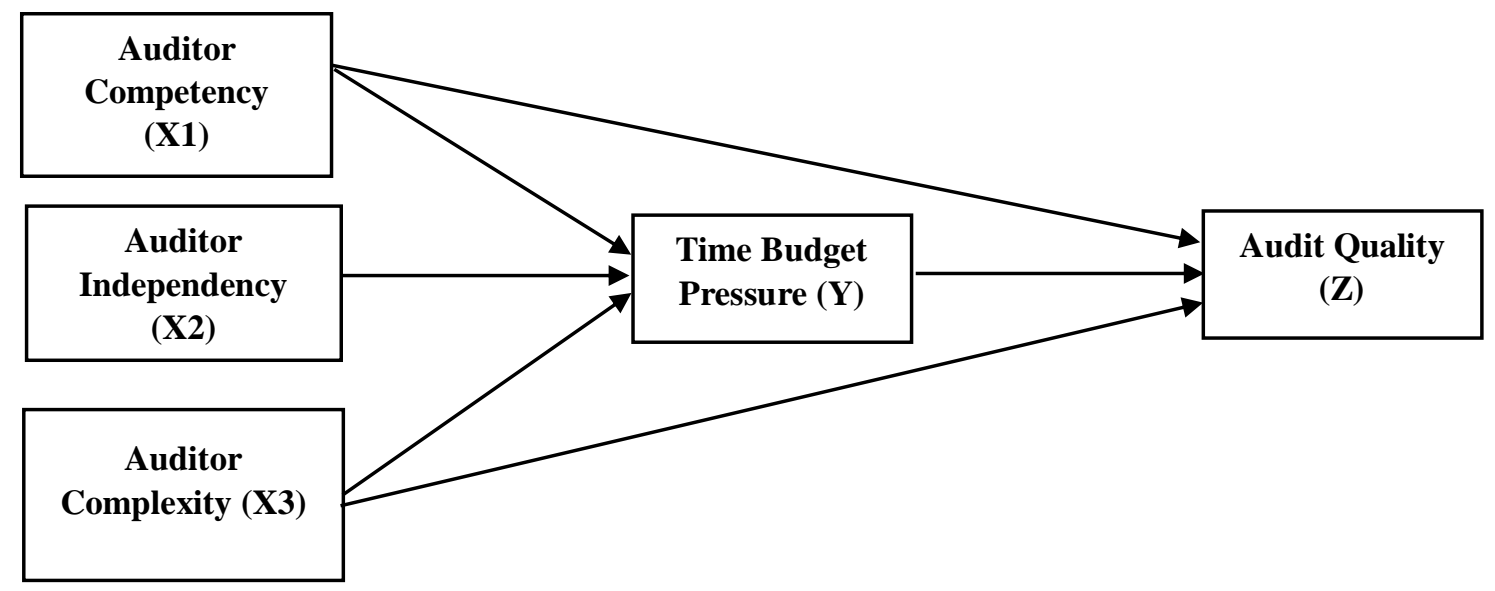

Figure 1. Research Model

Furthermore, in the data analysis section, we use the SEM-PLS analysis approach to test the hypothesis of this study. Consists of several demonstration relationships, namely testing direct, indirect and moderating relationships. However, before entering the hypothesis testing stage, several stages in the process of testing this study include measuring the distribution of respondents' answers then calculated using Smart-PLS to determine the standard deviation value, the average value of the distribution of respondents' answers, loading factor $>0.60$ (do Nascimento and da Silva Macedo, 2016); (Sarstedt et al., 2014); inner-model testing with assessment criteria $>0.60$ (i.e., cronbach alpha, composite reliability and AVE) (Andreev et al., 2009).

Furthermore, if the measurement data has been declared feasible as with the measurement criteria described above, then the next step is to measure the goodness of fit model by assessing the data testing criteria, i.e., Standardized Root Mean Square Residual and Normed Fit Index (SRMR < 0.80, NFI > 0.90) (Fassott et al., 2016; (Ringle et al., 2015). d_ULS and d_G with original value criteria (saturated model $>$ estimated model). The results of the demonstration of the Goodness fit model test are illustrated in table 4. Furthermore, the following testing stage tests the coefficient of determination and the F-test (R-Square and F-test), shown in Table 6. The last step of research testing is testing the hypothesis using the constant bootstrapping method with chi-square $(\mathrm{n}=255)$, determining the T-statistic value and P-Value value with the measurement criteria sig $<0.05$ as demonstrated in Table 7. In this study, the data collection method used a distributed questionnaire. To the entire study sample, the number of questions consisted of 39 questions with a distribution of answers using a Likert scale $(1=$ Totally Disagree; $2=$ Disagree; $3=$ Neutral; $4=$ Agree; $5=$ Totally Agree) which in detail can be seen in Table 1 .

Table 1. Variable Measurement

\begin{tabular}{l|l|l}
\hline \multicolumn{1}{c|}{ Variables } & Code & \multicolumn{1}{c}{ Item } \\
\hline \multirow{2}{*}{$\begin{array}{l}\text { Auditor } \\
\text { Competency } \\
\text { (AC) }\end{array}$} & $\mathrm{AC} 1$ & $\begin{array}{l}\text { To be able to understand the client's industry better, usually before } \\
\text { conducting an audit to find out about the client's industry background }\end{array}$ \\
\cline { 2 - 3 } & $\mathrm{AC} 2$ & $\begin{array}{l}\text { To conduct a good audit requires knowledge gained from the level of } \\
\text { formal education. }\end{array}$ \\
\cline { 2 - 3 } & AC3 & $\begin{array}{l}\text { Apart from formal education, to do a good audit, I also need other } \\
\text { knowledge in auditing. }\end{array}$ \\
\hline
\end{tabular}




\begin{tabular}{|c|c|c|}
\hline Variables & Code & Item \\
\hline & $\mathrm{AC4}$ & The special skills that I have can support the audit process that I do. \\
\hline & AC5 & The more numbers I audit, the better the audits I do. \\
\hline \multirow{5}{*}{$\begin{array}{l}\text { Auditor } \\
\text { Independency } \\
\text { (AI) }\end{array}$} & AI1 & $\begin{array}{l}\text { As a member of the audit team, I always carry out audits in accordance } \\
\text { with general auditing standards. }\end{array}$ \\
\hline & $\mathrm{AI} 2$ & $\begin{array}{l}\text { I make SPAP (Public Accountant Professional Standard) as a guideline } \\
\text { in carrying out reporting work }\end{array}$ \\
\hline & AI3 & Objective in making assessments \\
\hline & AI4 & Professional \\
\hline & AI5 & Skepticism and integrity \\
\hline \multirow{5}{*}{$\begin{array}{l}\text { Auditor } \\
\text { Complexity } \\
\text { (AC) }\end{array}$} & $\mathrm{AC} 1$ & $\begin{array}{l}\text { As an auditor, I understand that the difficulty level of audit assignments } \\
\text { from different types of clients is different, so experience is needed }\end{array}$ \\
\hline & AC2 & $\begin{array}{l}\text { Auditors need skills and attitudes to be able to perform multitasking } \\
\text { tasks, the ability to review and also the ability to consider audit scenarios }\end{array}$ \\
\hline & $\mathrm{AC} 3$ & $\begin{array}{l}\text { The auditor's memory is very limited, therefore the support of } \\
\text { personality factors and also the auditor's psychological and } \\
\text { psychological conditions is very important }\end{array}$ \\
\hline & $\mathrm{AC} 4$ & The ability of auditors to integrate issues is very important \\
\hline & AC5 & $\begin{array}{l}\text { The descriptions of various company backgrounds and the cases faced } \\
\text { are certainly different at every moment, therefore a reliable auditor is an } \\
\text { auditor who has good experience. }\end{array}$ \\
\hline \multirow{5}{*}{$\begin{array}{l}\text { Time Budget } \\
\text { Pressure (TBP) }\end{array}$} & TBP1 & $\begin{array}{l}\text { The auditor acts in a way to minimize loss or waste of time in carrying } \\
\text { out the audit. }\end{array}$ \\
\hline & TBP2 & $\begin{array}{l}\text { The auditor when making a time budget with the client must consider } \\
\text { the time limit for completing the audit so that the KAP obtains the best } \\
\text { results. }\end{array}$ \\
\hline & TBP3 & $\begin{array}{l}\text { Complete the audit on time Complete the audit on time, i.e. the auditor } \\
\text { reports the audit results in accordance with the planned budget }\end{array}$ \\
\hline & TBP4 & $\begin{array}{l}\text { The level of fulfillment of the achievement of the auditor's time budget } \\
\text { The level of fulfillment of the achievement of the achievement of the } \\
\text { auditor's time budget }\end{array}$ \\
\hline & TBP5 & $\begin{array}{l}\text { The auditor must know the responsibilities that must be completed and } \\
\text { the targets that must be achieved and are responsible for keeping the } \\
\text { audit process running efficiently }\end{array}$ \\
\hline \multirow{4}{*}{$\begin{array}{l}\text { Audit Quality } \\
\text { (AQ) }\end{array}$} & AQ1 & Auditors must have an attitude of professional skepticism \\
\hline & AQ2 & $\begin{array}{l}\text { Auditors are responsible for complying with auditing standards set by } \\
\text { the Indonesian Institute of Accountants }\end{array}$ \\
\hline & AQ3 & $\begin{array}{l}\text { The auditor must obtain sufficient knowledge of the business to identify } \\
\text { and understand events, transactions and practices that in the auditor's } \\
\text { judgment may have a significant impact on the financial statements. }\end{array}$ \\
\hline & AQ4 & $\begin{array}{l}\text { The management of the audited entity is responsible for following up on } \\
\text { recommendations as well as creating and maintaining a process and } \\
\text { information system to monitor the status of follow-up on the examiner's } \\
\text { recommendations }\end{array}$ \\
\hline
\end{tabular}

\section{RESULTS}

Characteristics of Respondents Based on Gender. This research was conducted on public accountants with a total of 35 respondents. What is disclosed are competency factors which include knowledge and experience. These independent factors include the length of relationship with clients, pressure from clients, peer-auditor reviews, non-audit services, and audit quality. Data was taken using an instrument in the form of a questionnaire that has 
been tested for validity and reliability. Table 2 presents data on the gender of the respondents studied.

Table 2. Data on Gender of Respondents

\begin{tabular}{cccc}
\hline No & Gender & n & \% \\
\hline 1 & Men & 23 & $65,71 \%$ \\
2 & Women & 12 & $34,29 \%$ \\
\hline & Total & 35 & $100 \%$ \\
\hline
\end{tabular}

Source: Processed primary data, 2021

Based on Table 1, 35 respondents from auditors, consisting of 23 males $(65.71 \%)$ and 12 females $(34.29 \%)$. It can be seen from the figure that there are more male respondents than female respondents.

Characteristics of Respondents Based on Working Period. An indication of the length of service is an auditor's experience calculated based on a time/year. So that auditors who have worked as auditors for a long time can be experienced, auditors. Because the longer you work as an auditor, the more you will be able to increase your knowledge and expand auditors' knowledge in the field of accounting and auditing.

Table 3. Respondents Work Period Data

\begin{tabular}{cccc}
\hline No & Length of work (years) & $\mathbf{n}$ & \% \\
\hline 1 & $<3$ & 1 & $2,86 \%$ \\
2 & $>3$ & 34 & $97,14 \%$ \\
\hline & Total & 35 & $100 \%$ \\
\hline
\end{tabular}

Source: Processed primary data, 2021

Table 2 shows that most auditors worked less than three years, i.e., one auditor, accounting for $2.86 \%$ of the total number of respondents. Meanwhile, 34 auditors have worked for more than three years or reached $97.14 \%$. This indicates that the dominant auditor in the chief research subject has had enough work experience, so it is assumed that his knowledge of the auditing world is quite broad.

Characteristics of Respondents by Position. The characteristics of research respondents based on their job positions at the public accounting firm where the respondent works are shown in table 4 below:

Table 4. Data on the Position of Respondents

\begin{tabular}{clcc}
\hline No & Position Level & n & \% \\
\hline 1 & First Auditor & 1 & $2,86 \%$ \\
2 & Young Auditor & 18 & $51,43 \%$ \\
3 & Associate Auditor & 16 & $45,71 \%$ \\
\hline & Total & 35 & $100 \%$ \\
\hline
\end{tabular}

Source: Processed primary data, 2021 
Table 4 shows that of the 35 auditors is, 1 or $2.86 \%$ is the first batch of auditors. At the same time, 18 or $51.43 \%$ of auditors are junior auditors, and 16 or $45.71 \%$ are middle auditors.

Statistical Result. The results of the demonstration of testing the validity and reliability of this study as shown in Table 4 show that overall the variables are declared valid and reliable. Auditor competency variable with Cronbach alpha value $=0.845, \mathrm{CR}=0.889$ and $\mathrm{AVE}=$ 0.716. auditor independence variable $(\mathrm{X} 2)$ with Cronbach alpha $=0.794, \mathrm{CR}=0.858$ and $\mathrm{AVE}=0.749$. Auditor Complexity variable with Cronbach alpha value $=0.764, \mathrm{CR}=0.841$ and $\mathrm{AVE}=0.715$. Time Budget Pressure $(\mathrm{Y})$ variable with Cronbach alpha $=0.791, \mathrm{CR}=$ 0.857 and $\mathrm{AVE}=0.746$. Variable Audit Quality $(\mathrm{Z})$ with a value of cronbach alpha $=0.808$, $\mathrm{CR}=0.868$ and $\mathrm{AVE}=0.769$. Furthermore, table 4 also states that the fit model test is stated to be good. SRMR value $=0.072<0.080$, and NFI $=0.091>0.90$.

Table 4. Validity and Reliability

\begin{tabular}{|c|c|c|c|c|c|c|}
\hline Variable & Code & $\begin{array}{l}\text { Loading } \\
\text { Factor }\end{array}$ & $\begin{array}{c}\text { Cronbach } \\
\text { Alpha }\end{array}$ & rho_A & $\begin{array}{l}\text { Composite } \\
\text { Reliability }\end{array}$ & AVE \\
\hline \multirow{5}{*}{$\begin{array}{l}\text { Auditor } \\
\text { Competency (X1) }\end{array}$} & Item1 & 0,789 & \multirow{5}{*}{0,845} & \multirow{5}{*}{0,849} & \multirow{5}{*}{0,889} & \multirow{5}{*}{0,716} \\
\hline & Item2 & 0,767 & & & & \\
\hline & Item3 & 0,771 & & & & \\
\hline & Item4 & 0,796 & & & & \\
\hline & Item5 & 0,801 & & & & \\
\hline \multirow{5}{*}{$\begin{array}{l}\text { Auditor } \\
\text { Independency } \\
\text { (X2) }\end{array}$} & Item6 & 0,769 & \multirow{5}{*}{0,794} & \multirow{5}{*}{0,807} & \multirow{5}{*}{0,858} & \multirow{5}{*}{0,749} \\
\hline & Item7 & 0,741 & & & & \\
\hline & Item8 & 0,702 & & & & \\
\hline & Item9 & 0,764 & & & & \\
\hline & Item10 & 0,811 & & & & \\
\hline \multirow{5}{*}{$\begin{array}{l}\text { Auditor } \\
\text { Complexity (X3) }\end{array}$} & Item11 & 0,766 & \multirow{5}{*}{0,764} & \multirow{5}{*}{0,772} & \multirow{5}{*}{0,841} & \multirow{5}{*}{0,715} \\
\hline & Item12 & 0,788 & & & & \\
\hline & Item13 & 0,746 & & & & \\
\hline & Item14 & 0,736 & & & & \\
\hline & Item15 & 0,744 & & & & \\
\hline \multirow{5}{*}{$\begin{array}{l}\text { Time Budget } \\
\text { Pressure (Y) }\end{array}$} & Item16 & 0,741 & \multirow{5}{*}{0,791} & \multirow{5}{*}{0,796} & \multirow{5}{*}{0,857} & \multirow{5}{*}{0,746} \\
\hline & Item17 & 0,744 & & & & \\
\hline & Item18 & 0,701 & & & & \\
\hline & Item19 & 0,698 & & & & \\
\hline & Item20 & 0,804 & & & & \\
\hline \multirow{6}{*}{ Audit Quality (Z) } & Item21 & 0,769 & \multirow{6}{*}{0,808} & \multirow{6}{*}{0,816} & \multirow{6}{*}{0,868} & \multirow{6}{*}{0,769} \\
\hline & Item22 & 0,795 & & & & \\
\hline & Item23 & 0,793 & & & & \\
\hline & Item24 & 0,728 & & & & \\
\hline & Item25 & 0,773 & & & & \\
\hline & Item26 & 0,769 & & & & \\
\hline
\end{tabular}


Table 4. Model Fit

\begin{tabular}{l|c|r|r|c}
\hline & Assessment criteria & $\begin{array}{c}\text { Saturated } \\
\text { Model }\end{array}$ & $\begin{array}{c}\text { Estimated } \\
\text { Model }\end{array}$ & Result \\
\hline SRMR & $<0.80$ & 0,072 & 0,071 & Fit \\
\hline d_ULS & saturated model $>$ estimated model & 6,111 & 6,516 & Fit \\
\hline d_G & saturated model $>$ estimated model & 3,861 & 4,809 & Fit \\
\hline Chi-Square & - & 35,774 & 35,951 & Fit \\
\hline NFI & $>0.90$ & 0,911 & 0,921 & Fit \\
\hline
\end{tabular}

Table 5 explains the measurement of discriminant validity, showing that testing the validity of the variable crosswise against other variables also offers the coefficient value $>$ 0.60 except for discriminant validity.

Table 5. Discriminant Validity

\begin{tabular}{l|l|l|l|l|l}
\hline & $(\mathbf{Z})$ & $(\mathbf{X 1})$ & $(\mathbf{X 3})$ & $(\mathbf{X 2})$ & $(\mathbf{Y})$ \\
\hline Audit Quality (Z) & 0,754 & & & & \\
\hline Auditor Competency (X1) & 0,577 & 0,785 & & & \\
\hline Auditor Complexity (X3) & 0,663 & 0,440 & 0,718 & & \\
\hline Auditor Independency (X2) & 0,707 & 0,591 & 0,539 & 0,741 & \\
\hline Time Budget Pressure (Y) & 0,709 & 0,444 & 0,732 & 0,600 & 0,739 \\
\hline
\end{tabular}

$\mathrm{R}$ squared is a number that ranges from 0 to 1 which indicates the magnitude of the combination of independent variables which together affect the value of the dependent variable. The closer to number one, the model issued by the regression will be better. The results from table 6 show that the R-Square value of the audit quality variable is 0.814 and the time budget pressure variable is 0.696 .

Table 6. R-Square

\begin{tabular}{l|r|r}
\hline & R Square & R Square Adjusted \\
\hline Audit Quality (Z) & 0,814 & 0,808 \\
\hline Time Budget Pressure (Y) & 0,696 & 0,690 \\
\hline
\end{tabular}

The value of $f$ square in this study shows that the magnitude of the effect of endogenous variables on exogenous variables. The endogenous variables in this study are audit quality and time budget pressure, while the exogenous variable in this study is the decision purchase. The criteria for evaluating f-square according to Henseler (2009) are as follows: $0.02 \leq \mathrm{f} 0.15=$ small effect, $0.15 ; 0.35=$ medium effect, $\mathrm{f} 0.35=$ large effect.

Table 7. F-Square

\begin{tabular}{l|c|c|c|c|c}
\hline & $(\mathrm{Z})$ & $(\mathrm{X} 1)$ & $(\mathrm{X} 3)$ & $(\mathrm{X} 2)$ & $(\mathrm{Y})$ \\
\hline Audit Quality (Z) & & & & & \\
\hline Auditor Competency (X1) & 0,171 & & & & 0,001 \\
\hline
\end{tabular}




\begin{tabular}{l|c|l|l|l|l}
\hline Auditor Complexity (X3) & 0,066 & & & & 0,556 \\
\hline Auditor Independency (X2) & & & & & 0,103 \\
\hline Time Budget Pressure (Y) & 0,189 & & & & \\
\hline
\end{tabular}

Furthermore, in table 8, namely the hypothesis testing stage, all hypotheses are declared accepted, the most dominant variable testing is shown in the demonstration of the auditor independence variable on time budget pressure with T-statitstic $=10,838$. As for the indirect test demonstration, the most dominant is as shown in the Auditor Complexity test which was intervened by Time Budget Pressure on Audit Quality.

Table 8. Hypothesis Result

\begin{tabular}{l|r|r|r|r}
\hline & $\begin{array}{c}\text { Sample } \\
\text { Mean }\end{array}$ & $\begin{array}{c}\text { Standard } \\
\text { Deviation }\end{array}$ & T Statistics & P Values \\
\hline Auditor Competency $\rightarrow$ Audit Quality & 0,296 & 0,049 & 6,015 & 0,000 \\
\hline Auditor Competency $\rightarrow$ Time Budget Pressure & 0,037 & 0,068 & 2,448 & 0,045 \\
\hline Auditor Complexity $\rightarrow$ Audit Quality & 0,233 & 0,073 & 3,253 & 0,001 \\
\hline Auditor Complexity $\rightarrow$ Time Budget Pressure & 0,568 & 0,053 & 10,838 & 0,000 \\
\hline Auditor Independency $\rightarrow$ Time Budget Pressure & 0,279 & 0,061 & 4,472 & 0,000 \\
\hline Time Budget Pressure $\rightarrow$ Audit Quality & 0,411 & 0,077 & 5,290 & 0,000 \\
\hline $\begin{array}{l}\text { Auditor Independency } \rightarrow \text { Time Budget Pressure } \\
\rightarrow \text { Audit Quality }\end{array}$ & 0,116 & 0,036 & 3,122 & 0,002 \\
\hline $\begin{array}{l}\text { Auditor Complexity } \rightarrow \text { Time Budget Pressure } \\
\rightarrow \text { Audit Quality }\end{array}$ & 0,233 & 0,049 & 4,774 & 0,000 \\
\hline $\begin{array}{l}\text { Auditor Competency } \rightarrow \text { Time Budget Pressure } \\
\rightarrow \text { Audit Quality }\end{array}$ & 0,014 & 0,028 & 2,938 & 0,032 \\
\hline
\end{tabular}

\section{DISCUSSION}

At work, competence is an essential aspect in determining worker performance. Most workers will produce effective performance if they have knowledge, skills, and behavior (knowledge, skills, and attitude) that are pretty good and can be applied simultaneously. Knowledge, skills, and attitudes. These three things may already be familiar to us. Where knowledge means knowledge, skill implies skill, and attitude means attitude. Knowledge, skills, and attitude are three competencies that everyone should have. Every job often requires a combination of these three things concerning the field of auditing. In each audit engagement, the auditor must develop an audit plan. Audit planning aims to ensure that quality, economical, efficient, and effective audit objectives can be achieved. In planning the work program, the auditor must understand the client's business. In carrying out the audit, the auditor must act as an expert in accounting and auditing. The acquisition of expertise begins with formal education, which is further expanded through experience and practice. In addition, auditors must undergo adequate technical training that includes technical aspects and general education. An auditor must continuously follow developments that occur in business and his profession. An auditor must study, understand, and apply new accounting principles and auditing standards as professional organizations apply. To support professionalism as a public accountant, the auditor in carrying out audit duties must be guided by the audit standards used by the Indonesian Institute of Accountants (IAI), namely 
general standards, fieldwork standards, and reporting standards. The available standard reflects the personal qualities that must be owned by an auditor, which requires the auditor to have sufficient technical expertise and training in carrying out audit procedures. Because the audit is a process to reduce the misalignment of information that exists between managers and shareholders by using outside parties to provide ratification of financial statements, users of financial statements, especially shareholders, will make decisions based on reports made by auditors regarding the ratification of the company's financial statements.

The results of this study support the first hypothesis that competence affects audit quality. This means that audit quality can be achieved if the auditor has good competence. These competencies consist of two dimensions, namely experience and knowledge. As the spearhead of the implementation of audit tasks, auditors must continuously improve their knowledge so that the application of knowledge can be maximized in practice. The maximum knowledge application will undoubtedly align with the increasing experience possessed. The results of this study support research conducted by (Zeng et al., 2019) that experience and knowledge are important factors related to the provision of audit opinions, wherein this study is included in risk audit as an indicator of audit quality. According to general standards, auditors are required to have sufficient work experience in the profession they are engaged in and are required to have technical qualifications and experience in the industry their clients are involved in. Experience will also impact every decision taken in implementing the audit, so we hope that every decision taken is the right decision. This indicates that the longer the auditor's tenure, the better the audio quality. Independence has a substantial impact on audit quality. This is consistent with the second hypothesis that competence significantly affects audit quality. This result follows the research of (Botha et al., 2020) that showed that the length of time the auditor cooperates with the client (tenure) affects audit quality, where the assignment is related to independence. The opinion of (Liahmad et al., 2020), which states that independence is essential in addition to the auditor's technical ability, is also following the results of this study. The auditor must have the ability to collect any information needed in making audit decisions, which an independent attitude must support. It is undeniable that an independent perspective is inherent in the auditor, so independence has become an absolute requirement that must be possessed. It is not easy to maintain independence and keep it on track. Cooperation with clients that is too long can cause vulnerabilities to the auditor's independence. Not to mention the various facilities provided by the client during the audit assignment for the auditor. The auditor can be "easy to control" by the client because the auditor is in a dilemmatic position.

(Liu and Lai, 2012) found an inverse relationship between task complexity and audit quality at a certain level. The higher the complexity of the task, the lower the audit quality will be and vice versa. (Liu and Lai, 2012) also found that audit complexity that arises due to the higher variability and ambiguity of auditing tasks indicates the cause of the decline in audit quality. In such situations, auditors tend to behave dysfunctionally and prioritize the interests of clients rather than the objectivity of the audit results. However, (Putri et al., 2021) finds different effects, namely that task complexity does not affect the judgment made by the auditor in determining his audit opinion. These studies indicate that task complexity is not consistent as a factor affecting audit quality. Therefore, further research is necessary to decide on task complexity in audit quality..

This study empirically proves that all tested variables have a significant effect either simultaneously or partially, except for audit complexity, which indirectly affects audit 
quality. Audit quality is determined by two things, namely competence and independence. Research on competence shows that the accounting profession is becoming unattractive and displaced by other occupations. This study also provides empirical evidence that experience will affect the auditor's ability to detect errors, and the training provided will increase expertise in conducting audits. For this reason, input from public accounting firms and professional organizations is needed to develop formal accounting education and accounting training. Research on independence shows that public accountants are influenced by the urge to retain their audit clients in making decisions. But on the other hand, several forces can reduce this influence. The study results also provide evidence that reports users perceive the separation of audit staff from staff who perform consulting services to increase the independence of public accountants. Theoretical and managerial Implication: This study found the influence of knowledge and experience on audit quality. Therefore, auditors are expected to maintain and improve their knowledge and expertise to create good audit quality and maintain audit quality so that the credibility of audit results in the eyes of users of financial statement information can be maintained. In addition, junior auditors will increase their experience and knowledge as an auditor. In addition, a review of the results of the auditor's examination must be carried out to ensure that the investigation carried out follows applicable professional standards and is of high quality. To increase knowledge, auditors are advised to do other things beside auditing that can increase audit quality, namely by obtaining a certificate in auditing, attending seminars, or specific pieces of training related to audit quality. Then, to improve the experience for auditors, it is recommended to increase the number of flight hours in auditing and maintain or enhance their auditing results for good audit quality. As for clients and stakeholders, the results of this study can increase their knowledge of the factors that influence auditors in carrying out quality audit work because the higher the ability and the higher the experience of an auditor, the higher the audit quality that can be achieved.

\section{CONCLUSION}

Audit quality is a characteristic or description of audit practices and results based on auditing standards and quality control standards that measure the implementation of the duties and responsibilities of an auditor's profession. Audit quality relates to how well a job is done compared to predetermined criteria. Audit quality is all about possibilities (probability). While carrying out their duties, the auditor can find violations in the client's accounting system and report them in the audited financial statements. The auditor is guided by auditing standards and the relevant public accountant code of ethics. In detecting misstatements, the auditor must have an attitude of professional skepticism, namely, a perspective that includes a questioning mind and critical evaluation of audit evidence. Misstatements can occur due to error or fraud if the financial statements contain misstatements whose impact individually or as a whole is significant enough to cause the financial statements not to be presented fairly in all respects, following financial accounting standards. "Ethics is a moral principle and action that forms the basis of a person's activities. What he does is seen by society as a commendable act and increases one's dignity and honor. Independence means a mental attitude free from influence, not controlled by other parties, not dependent on others. Independence also means the auditor is honest in considering facts, 
and there is an impartial, objective consideration in the auditor in formulating and expressing his opinion.

\section{REFERENCES}

Ab Wahid, R., and Grigg, N. P. (2020). A draft framework for quality management system auditor education: findings from the initial stage of a Delphi study. The TQM Journal.

Agusti, R., dan Pertiwi, N. P. (2013). Pengaruh Kompetensi, Independensi dan Profesionalisme Terhadap Kualitas Audit (Studi Empiris Pada Kantor Akuntan Publik Se Sumatera). Jurnal Ekonomi, 21(03).

Agyei-Mensah, B. K. (2019). The effect of audit committee effectiveness and audit quality on corporate voluntary disclosure quality. African Journal of Economic and Management Studies.

Ahmad, Z., and Taylor, D. (2009). Commitment to independence by internal auditors: the effects of role ambiguity and role conflict. Managerial Auditing Journal.

Aida, N. (2021). Work Experience, Obedience Pressure and Task Complexity on Audit Judgment. Golden Ratio of Auditing Research, 1(2), 61-69.

Alzeban, A. (2019). The impact of audit committee, CEO, and external auditor quality on the quality of financial reporting. Corporate Governance: The International Journal of Business in Society.

Andreev, P., Heart, T., Maoz, H., and Pliskin, N. (2009). Validating formative partial least squares (PLS) models: methodological review and empirical illustration.

Athavale, M., Guo, Z., Meng, Y., and Zhang, T. (2022). Diversity of signing auditors and audit quality: Evidence from capital market in China. International Review of Economics \& Finance.

Aziz, A., Muda, I., and Situmeang, C. (2021). Effect of Auditor Ethics, Complexity, Audit Fees, Auditor Motivation, and Time Budget Pressure on Audit Quality for All Members of the Indonesian Institute of Certified Public Accountants. Budapest International Research and Critics Institute (BIRCI-Journal): Humanities and Social Sciences, 4(4).

Botha, E., Helminen, M., Kaunonen, M., Lubbe, W., and Joronen, K. (2020). Mothers' parenting self-efficacy, satisfaction and perceptions of their infants during the first $\begin{array}{lllll}\text { days } & \text { postpartum. } & \text { Midwifery, } & 82760 .\end{array}$ https://doi.org/https://doi.org/10.1016/j.midw.2020.102760

Broberg, P., Tagesson, T., Argento, D., Gyllengahm, N., and Mårtensson, O. (2017). Explaining the influence of time budget pressure on audit quality in Sweden. Journal of Management \& Governance, 21(2), 331-350.

Carrera, N., and Van Der Kolk, B. (2021). Auditor ethics: do experience and gender influence auditors' moral awareness? Managerial Auditing Journal.

Cipriani, G. (2010). The EU budget: responsibility without accountability?

Daniels, B. W., and Booker, Q. (2011). The effects of audit firm rotation on perceived auditor independence and audit quality. Research in Accounting Regulation, 23(1), $78-82$.

Dewayanto, T. (2011). Analisis faktor-faktor yang mempengaruhi penerimaan opini audit going concern pada perusahaan manufaktur yang terdaftar di bursa efek indonesia. Fokus Ekonomi: Jurnal Ilmiah Ekonomi, 6(1). 
do Nascimento, J. C. H. B., and da Silva Macedo, M. A. (2016). Structural Equation Models using Partial Least Squares: an Example of the Application of SmartPLS® in Accounting Research. Revista de Educação e Pesquisa Em Contabilidade, 10(3).

Durocher, S., and Fortin, A. (2021). Financial statement users' institutional logic. Journal of Accounting and Public Policy, 40(2), 106819.

Endri, E. (2020). The effect of task complexity, independence and competence on the quality of audit results with auditor integrity as a moderating variable. International Journal of Innovation, Creativity and Change, 12(12).

Fassott, G., Henseler, J., and Coelho, P. S. (2016). Testing moderating effects in PLS path models with composite variables. Industrial Management \& Data Systems.

Furiady, O., and Kurnia, R. (2015). The effect of work experiences, competency, motivation, accountability and objectivity towards audit quality. Procedia-Social and Behavioral Sciences, 211, 328-335.

Imen, F., and Anis, J. (2020). The moderating role of audit quality on the relationship between auditor reporting and earnings management: empirical evidence from Tunisia. EuroMed Journal of Business.

Jaya, T. E., and Irene, C. (2016). Skepticism, Time Limitation of Audit, Ethics of Professional Accountant and Audit Quality (Case Study in Jakarta, Indonesia). Review of Integrative Business and Economics Research, 5(3), 173-182.

Kertarajasa, A. Y., Marwa, T., and Wahyudi, T. (2019). The effect of competence, experience, independence, due professional care, and auditor integrity on audit quality with auditor ethics as moderating variable.

Li, Y. (2010). The case analysis of the scandal of Enron. International Journal of Business and Management, 5(10), 37.

Liahmad, L., Rusnindita, K., and Utami, Y. P. (2020). Effect of Competence, Independence, and Auditor Experience of Audit Quality (Study of Public Accountants in Malang City Public Accountant Office). International Joint Conference on Science and Technology, 2(1), 152-159.

Liu, C. L., and Lai, S. M. (2012). Organizational complexity and auditor quality. Corporate Governance: An International Review, 20(4), 352-368.

Liu, C., and $\mathrm{Xu}, \mathrm{C}$. (2021). The effect of audit engagement partner professional experience on audit quality and audit fees: early evidence from Form AP disclosure. Asian Review of Accounting.

Moroney, R., and Trotman, K. T. (2016). Differences in auditors' materiality assessments when auditing financial statements and sustainability reports. Contemporary Accounting Research, 33(2), 551-575.

Natsir, M., Pattawe, A., Haris, N., and Zahra, F. (2021). The effects of work experience, ethical profession, and auditor independence on auditing performance of supervisory agency in central sulawesi Indonesia. Academy of Entrepreneurship Journal, 27(4), $1-9$.

Putri, A. P., Nabila, N., Augustin, V., and Fellia, F. (2021). Audit Tenure, Auditor Experience, Independency, And Task Complexity On Audit Judgement. Jurnal Riset Akuntansi Kontemporer, 13(1), 7-12.

Rajgopal, S., Srinivasan, S., and Zheng, X. (2021). Measuring audit quality. Review of Accounting Studies, 26(2), 559-619.

Ringle, C., Da Silva, D., and Bido, D. (2015). Structural equation modeling with the 
SmartPLS. Bido, D., Da Silva, D., \& Ringle, C.(2014). Structural Equation Modeling with the Smartpls. Brazilian Journal Of Marketing, 13(2).

Samagaio, A., and Felício, T. (2022). The influence of the auditor's personality in audit quality. Journal of Business Research, 141, 794-807.

Sarstedt, M., Ringle, C. M., Henseler, J., and Hair, J. F. (2014). On the emancipation of PLS-SEM: A commentary on Rigdon (2012). Long Range Planning, 47(3), 154-160.

Schmidthuber, L., Hilgers, D., and Hofmann, S. (2020). International Public Sector Accounting Standards (IPSASs): A systematic literature review and future research agenda. Financial Accountability \& Management.

Setyowati, W., Kurniawan, P. C., Mardiansyah, A., Harahap, E. P., and Lutfiani, N. (2021). The Role Of Duty Complexity As A Moderation Of The Influence Auditor's Professional Knowledge And Ethics On Audit Quality. Aptisi Transactions on Management (ATM), 5(1), 20-29.

Sofyan, A., Agusti, R., dan Marbun, A. B. (2015). Pengaruh Kompetensi, Independensi, Profesionalisme, Pengalaman Kerja dan Komitmen Organisasi Terhadap Kualitas Audit (Studi Empiris Pada Kantor Akuntan Publik Di Pekanbaru, Padang Dan Medan). Riau University.

Svanberg, J., and Öhman, P. (2013). Auditors' time pressure: does ethical culture support audit quality? Managerial Auditing Journal.

Trotman, A. J., and Trotman, K. T. (2010). The intersection of family business and audit research: Potential opportunities. Family Business Review, 23(3), 216-229.

Usmany, P. (2021). The Influence of Self Efficacy and Effort on Auditor Performance Specific Experience as Antecedent Variables (Empirical Study on BPK-RI in Indonesia). Budapest International Research and Critics Institute (BIRCI-Journal): Humanities and Social Sciences, 4(4), 12366-12379.

Zahmatkesh, S., and Rezazadeh, J. (2017). The effect of auditor features on audit quality. Tékhne, 15(2), 79-87.

Zeng, Y., Chen, G., Li, K., Zhou, Y., Zhou, X., and Li, K. (2019). M-Skyline: Taking sunk cost and alternative recommendation in consideration for skyline query on uncertain data. Knowledge-Based Systems, 163, 204-213. https://doi.org/https://doi.org/10.1016/j.knosys.2018.08.024 